\title{
Recovery of Leachate from Everbearing Strawberry Cultivation as an Element of Retardation
}

\author{
Michał Kopeć ${ }^{*}$, Monika Mierzwa-Hersztek ${ }^{1}$, Krzysztof Gondek ${ }^{1}$, Tomasz Zaleski², \\ Stanisław Bogdał', Monika Bieniasz', Jan Błaszczyk', Elżbieta Kaczmarczyk4, \\ Jarosław Knaga ${ }^{5}$, Bogusława Łapczyńka-Kordon ${ }^{6}$, Jacek Nawrocki ${ }^{7}$, Michał Pniak ${ }^{8}$
}

1 Department of Agricultural and Environmental Chemistry, University of Agriculture in Krakow, al. Mickiewicza 21, 31-120 Krakow

2 Institute of Soil Science and Agrophysics, Department of Soil Science and Soil Protection, University of Agriculture in Krakow, al. Mickiewicza 21, 31-120 Krakow

3 Stanflex-Polski Instytut Truskawki Sp. z o.o., ul. L. Petrażyckiego 20/1, 30-399 Krakow

${ }^{4}$ Department of Horticulture, University of Agriculture in Krakow, al. 29 Listopada 54, 31-425 Krakow

${ }^{5}$ Department of Bioprocess Engineering, Power Engineering and Automation, University of Agriculture in Krakow, ul. Balicka 116 b, 30-149 Krakow

${ }^{6}$ Department of Mechanical Engineering and Agrophysics, ul. Balicka 120, 30-149 Krakow

7 Department of Botany, Plant Physiology and Protection, University of Agriculture in Krakow, al.29 Listopada 54, 31-425 Krakow, 126625262

8 BIOCONT Polska, al. 29 Listopada 56a, 31-425 Krakow

* Corresponding author's e-mail: m.kopec@urk.edu.pl

\begin{abstract}
Due to the scale of leachate formation in soilless crop technologies, water and nutrient management is becoming more and more important and can determine the production efficiency. Closed systems, including recirculation or recovery of leachate from fertilisation, are an opportunity to retard unfavourable nutrients and water, which has become an important element of modern technology and has a significant environmental impact. Re-application of leachate, despite very low concentrations of macro- and microelements, must be performed taking into account the properties of the substrate/soil, the requirements of the plant and the dose of leachate. In the case of maize cultivation on two soils, irrigation of the crop with leachate from soilless strawberry production led to the soil salinization. From the point of view of the leachate fertiliser value, the source of water for fertigation and the component concentration in the media, which can cause ion imbalance, remain important.
\end{abstract}

Keywords: retardation of adverse environmental changes, leachate from soilless crops, maize

\section{INTRODUCTION}

Industrial agriculture and other forms of management are nowadays a serious burden on the natural environment. Thus, the strategy of caring for sustainable development and the tasks performed as part of ecological engineering focus on retarding the transformation pace of widely understood resources (Kostecka 2019). Water and soil are essential factors of agricultural production. However, today, solutions are being sought to reduce the risks posed by these elements. Access to appropriate quality water is one of the basic factors that influence yield quantity and quality (Syliwoniuk-Wapowska 2017). In many crops, irrigation and drainage issues are key to maintaining production. These problems are increasingly being raised in the context of climate changes, which are accompanied by extremes, such as long-term droughts that increase 
the water deficit. The importance of rainwater in plant production is highlighted by Marosz (2015). Rainwater retention can significantly reduce production costs and will have a very positive effect on the environment if used more widely. Possible water management disorders, especially in soilless crops, result in yield loss. Especially in intensive production, such as horticulture, water management is very important. In soilless crops, about $70 \%$ of the supplied leachate medium is used by plants (Kaniszewski 2015). Excess leachate medium is defined as leakage, overflow or drainage water and should be treated as waste with code 020183 .

After appropriate preparation, leachate from soilless crops can be recovered (Bryszewski 2019) and reused for feeding the plants (closed systems with recirculation) or collected in reservoirs and used for fertilising other crops (open system without recirculation) (Żarnowiec et al. 2014, Kaniszewski 2015). Due to the significant costs of using the first method of leachate management mentioned above, open systems, i.e. systems from which the leachate is discharged outside the greenhouse, still prevail in most horticultural farms in Poland. Greenhouses and associated soilless crops account for a small share of the total area used for agriculture. The problem is that the means of production, including fertilisers, are concentrated to a large extent in order to obtain certain productivity per area unit. This concentration may significantly deteriorate the environment. The lack of leachate collection systems results in groundwater pollution (Dyśko et al. 2013).

When considering the water balance in intensive plant production, one takes into account its supply to the system as well as its dispersion and losses. The water used in plant production, particularly in soilless crops, must meet the criteria for the content of individual elements or compounds. Exceeding the acceptable content of ingredients taken up by plants has a negative impact on their development. This is due to disturbances in physiological processes, such as ionic imbalance. These disturbances may be caused by the interaction of ions in the solution. In addition to chemical and biochemical problems, technological problems also must be noted. The precipitation of compounds in the form of sediments clogs up the installation and the fertiliser plan does not provide for concentration in the leachate medium, since the measuring equipment (most often for measuring electrolytic conductivity) does not react properly to concentrates and acid. The concept of urban agriculture is more and more often recognised by not only scientists, but also consumers. The rationale and multifunctionality of urban agriculture is the subject of many studies (Górna and Górny 2019, Mojski et al. 2018). The basis for developing this technology is to shorten delivery logistics and achieve greater efficiency. The development of this form of agriculture is also justified by the use of water resources. For example, plants grown in some technologies can use up to $95 \%$ less water compared to conventional cultivation technologies (Stankiewicz 2017). Crops under controlled conditions allow for another element of retarding adverse environmental changes, namely the reduced use of chemical plant protection products. This is accompanied by increased efficiency in the use of fertilisers and energy, and this increases the production per area unit up to 75 times compared to traditional cultivation.

Areas of urban agriculture, including vertical farms, are specific installations where attention should be paid to closing the water and matter cycle, which will undoubtedly contribute to a more efficient use of resources on the Earth. The issue of recovering leachate water from crops is a practical element of retarding the use of resources, both water and nutrients. In this area, the potential of the post-consumer substrate also deserves a closer look. Among the various solutions, the need for post-consumer use of coconut fibre should be particularly noted.

The experiment sought to identify whether it is possible to protect ash nutrients as a result of using leachate in the early growing season and whether there is a risk to the environment from saturating the soil with leachate due to transpiration. The authors believe that controlled introduction of leachate water from horticultural production into the environment or its recirculation is a form of more effective application of fertiliser components used in soilless crops.

\section{MATERIAL AND METHODS}

Leachate waters were obtained from the experimental plantation of Polski Instytut Truskawki Sp. z o.o. located in Tyniec near Krakow, geographical coordinates: $50^{\circ} 02^{\prime} 11^{\prime \prime} \mathrm{N}$ and 19.81'19'E. The cultivation of everbearing strawberry (4 ha) was carried out in gutter system 
under covers on an inert medium, i.e. in mats with coconut substrate in white $1000 \mathrm{~mm} \times 200 \mathrm{~mm} \times$ $100 \mathrm{~mm}$ foil. Before planting strawberries, mat buffering was carried out with a calcium nitrate solution $(\mathrm{pH}=5.5, \mathrm{EC}=1.2-1.7 \mathrm{mS} / \mathrm{cm})$. San Andreas ${ }^{\circledR} \quad$ strawberries (Fragaria $\times$ ananassa Duch) were grown annually. After the growing season, the crop was removed because of the risk of overwintering and the threat from pathogens. Six overflow stations were installed on the plantation. These were places where, due to the change of the gutter inclination over a distance of 4 linear meters and holes, it was possible to collect leachate, monitor its volume and chemical composition. To control the chemical composition of leachate from overflows, samples were taken from June to November. A leachate reservoir was installed on the plantation.

During the cultivation, the following doses of fertilisers (per linear meter-mat) were used: calcium nitrate $-156.8 \mathrm{~g}$; ammonium nitrate $-3.587 \mathrm{~g}$; magnesium nitrate - 34.97; DTPA iron chelate 7\% $\mathrm{Fe}-2.130 \mathrm{~g}$; EDDHA iron chelate $6 \% \mathrm{Fe}-2.461$; monopotassium phosphate $-22.51 \mathrm{~g}$; potassium nitrate $-34.26 \mathrm{~g}$; magnesium sulphate $-17.70 \mathrm{~g}$; manganese sulphate - $0.760 \mathrm{~g}$; EDTA manganese chelate $13 \%-1.875 \mathrm{~g}$; zinc sulphate $-0.334 \mathrm{~g}$; copper sulphate $-0.067 \mathrm{~g}$; borax $-0.103 \mathrm{~g}$; sodium molybdate $-0.021 \mathrm{~g}$; nitric acid $-86.92 \mathrm{~g}$.

The leachate samples taken at the plantation were cooled to approx. $4{ }^{\circ} \mathrm{C}$ and transported to the laboratory immediately. The $\mathrm{pH}$ value and electrical conductivity (EC) were determined in the samples. For nutrient determination, the leachate samples were mixed with diluted (1:2) nitric acid (leachate : acid ratio of $1: 10$ ). In the resulting solutions, selected nutrients were determined using ICP-OES method and PerkinElmer 7100 DV apparatus (Oleszczuk et al. 2007).

In the experiment, the soil was saturated with the leachate obtained from the reservoir (Irrigation with the leachate) compared to the soil irrigated with distilled water (Control). The water demand of the cultivated plant was caused by transpiration and consisted of infiltration. No additional fertilisation was applied in both treatments. The pot experiment was carried out on two extreme soils (acidic soil $\mathrm{pH}_{\mathrm{KCl}}-4.14$ and alkaline soil $\mathrm{pH}_{\mathrm{KCl}}$ - 7.68). The first soil had a granulometric composition of silty-clayey soil $(1.88 \% \mathrm{C})$, the second one was silty-sandy soil $(0.59 \% \mathrm{C})$. In $20 \mathrm{~cm}$ high vases holding $2 \mathrm{~kg}$ of soil, 6 seeds of FAO Karpotis 290 maize were planted. After
45 days, the biomass was collected, dried and the amount of dry matter was calculated, and soil samples were taken.

On the last day of the experiment, the colour parameters of young leaves in each of the fertiliser combinations were measured with the 3Color CP21- $8 \mathrm{~mm}$ colorimeter with a screen and Color QC software. The device was used to measure leaf greenness in the $\boldsymbol{L} \boldsymbol{a} \boldsymbol{b}$ colour space, which allows for a three-chromatic colour perception model. The a-axis represents the proportion of green or red in the analysed colour, with green hues having a negative value and red hues having a positive value. The $\mathbf{b}$-axis represents the proportion of blue or yellow in the analysed colour, with blue hues having a negative value and yellow hues having a positive value. The scales of axes $\mathbf{a}$ and $\mathbf{b}$ extend between -150 and +100 and -100 and +150 , regardless of the fact that some values do not have a colour equivalent. The $\mathbf{L}$ axis describes the brightness of the colour in the range from 0 to 100 .

\section{RESULTS AND DISCUSSION}

Under the plantation conditions, the consumption of leachate medium and the amount of leachate produced are highly variable. This results mainly from the phase of plant development and meteorological conditions affecting the transpiration level (Kopeć et al. 2019). In the case of cultivation of everbearing strawberry on soilless substrate in mats, during the vegetation period, leachate medium was fed to the drip head every day in the amount from $0 \mathrm{dm}^{3}$ on rainy days to $1.8 \mathrm{dm}^{3}$ on sunny days, which corresponded to $0-30$ waterings per day. Based on the data recorded on the plantation, the leachate medium volume (inlet) per running meter was calculated and it amounted to $826.5 \mathrm{dm}^{3}$. The estimated value per 1 ha of plantation area was $6612 \mathrm{~m}^{3}$. On the other hand, the average total overflow during the vegetation period was $32.2 \%$ of the total leachate medium volume.

According to Malorgio et al. (2001), in rose cultivation carried out with an open fertilisation system, $2123 \mathrm{~m}^{3} \cdot \mathrm{ha}^{-1}$ of fertiliser solution containing $1477 \mathrm{~kg}$ of nitrogen was uncontrolledly discharged into the ground of the greenhouse in an annual cycle. In the study of Dyśko (2007), in the cultivation of tomato on rockwool (from the beginning of April to the end of September) 
in the open system, the consumption of leachate medium was $10220 \mathrm{~m}^{3} \cdot \mathrm{ha}^{-1}$, while overflow was $3082 \mathrm{~m}^{3} \cdot \mathrm{ha}^{-1}$. The consumption of mineral components was $9.5 \mathrm{t} \cdot \mathrm{ha}^{-1}$ of which $4.7 \mathrm{t} \cdot \mathrm{ha}^{-1}$ (including over $1000 \mathrm{~kg}$ of nitrogen) was discharged in drainage waters into the ground (Kaniszewski 2015). In the case of strawberry cultivation, the leachate medium volume is smaller as a result of the lower plant weight compared to tomatoes or cucumbers. However, these volumes are also significant and require special care when introduced into the environment.

As stated by Dyśko et al. (2013), who studied the effect of soilless greenhouse crops on the contamination of shallow groundwater with fertiliser leachate in open systems, the water directly under the soilless crops was contaminated with almost all fertiliser components that were present in the fertiliser media used. This involved mainly contamination with nitrogen, potassium, calcium and magnesium and was independent of tomato or cucumber cultivation. The content of fertiliser components in groundwater decreased with increasing distance from cultivation facilities (sources of leachate leakage to soil). SanjuanDelmás et al. (2020) showed that, on average, $51 \%$ of the nutrients are leached. This amount can be reduced, for example, by returning it back to circulation (closed hydroponic systems). $\mathrm{Nu}-$ trients are also precipitated in soilless substrates.
Sanjuan-Delmás et al. (2020) determined that 3 to $7 \%$ of the nitrogen, phosphorus or calcium input was retained in perlite. These authors highlighted that there is a need for studies on the measurement accuracy, but, at the same time, argued that these are significant amounts that should not be randomly dispersed in the environment. Particular attention is paid to alkaline bivalent calcium and magnesium cations which are the cause of precipitation of other elements in the substrate.

The additional reduction of nutrient and water doses in the growing period has its limitations and any excessive correction can lead to agronomic problems and product loss. Table 1 shows the variability of the chemical composition of leachate from the soilless everbearing strawberry cultivation during the growing season and the chemical composition of leachate from the reservoir used in the maize experiment.

The maize yield harvested from the vase differed significantly both on acidic and alkaline soils between the control and leachate treatments (Table 2). However, plants showed opposite reactions to the factor. For acidic soil, the applied leachate increased the yield by $86 \%$ compared to the treatment where plants were getting water. In this case, the chemical composition of the leachate had a positive effect on plant development. For alkaline soil, the leachate application reduced the yield by $37 \%$ compared to the control. Under

Table 1. Average (from the growing season) chemical composition of leachates from strawberry soilless culture and one-time determination of the chemical composition in the leachate tank in November (Kopeć et al. 2019)

\begin{tabular}{|c|c|c|c|c|c|}
\hline \multirow{2}{*}{ Parameter } & \multirow{2}{*}{ Unit } & \multicolumn{3}{|c|}{ Growing season } & Reservoir \\
\cline { 3 - 6 } & & Average & $\mathrm{SD}^{2}$ & $\mathrm{~V}^{3}[\%]$ & 7.89 \\
\hline $\mathrm{pH}$ & & 7.36 & 0.95 & & 3.49 \\
\hline $\mathrm{EC}$ & $\mathrm{mS} \cdot \mathrm{cm}^{-1}$ & 2.619 & 0.662 & 25.3 & 0.138 \\
\hline $\mathrm{B}$ & $\mathrm{mg} \cdot \mathrm{dm}^{-3}$ & 0.168 & 0.071 & 42.5 & 164.3 \\
\hline $\mathrm{Ca}$ & $\mathrm{mg} \cdot \mathrm{dm}^{-3}$ & 172.49 & 66.54 & 38.5 & 0.157 \\
\hline $\mathrm{Cu}$ & $\mathrm{mg} \cdot \mathrm{dm}^{-3}$ & 0.115 & 0.085 & 73.9 & 1.073 \\
\hline $\mathrm{Fe}$ & $\mathrm{mg} \cdot \mathrm{dm}^{-3}$ & 1.085 & 0.546 & 50.3 & 132.85 \\
\hline $\mathrm{K}$ & $\mathrm{mg} \cdot \mathrm{dm}^{-3}$ & 134.36 & 90.07 & 67.0 & 0.025 \\
\hline $\mathrm{Li}$ & $\mathrm{mg} \cdot \mathrm{dm}^{-3}$ & 0.0140 & 0.0076 & 54.0 & 0.485 \\
\hline $\mathrm{Mg}$ & $\mathrm{mg} \cdot \mathrm{dm}^{-3}$ & 55.71 & 32.53 & 58.4 & 0.267 \\
\hline $\mathrm{Mn}$ & $\mathrm{mg} \cdot \mathrm{dm}^{-3}$ & 1.232 & 1.385 & 112.4 & 3.94 \\
\hline $\mathrm{Mo}$ & $\mathrm{mg} \cdot \mathrm{dm}^{-3}$ & 0.002 & 0.003 & 150.0 & 329.75 \\
\hline $\mathrm{N}$ & $\mathrm{mg} \cdot \mathrm{dm}^{-3}$ & 2.034 & 3.51 & 172.5 & 8.63 \\
\hline $\mathrm{Na}$ & $\mathrm{mg} \cdot \mathrm{dm}^{-3}$ & 224.3 & 152.0 & 67.9 & 1.579 \\
\hline $\mathrm{P}$ & $\mathrm{mg} \cdot \mathrm{dm}^{-3}$ & 12.24 & 14.28 & 116.7 & 1.860 \\
\hline $\mathrm{Si}$ & $\mathrm{mg} \cdot \mathrm{dm}^{-3}$ & 3.490 & 1.989 & 57.0 & 75.0 \\
\hline
\end{tabular}

Note: 1) EC - electrical conductivity; 2) SD - standard deviation; 3) V - variance coefficient. 
Table 2. Yield and chemical composition of maize and leaf greenness parameters after 45 days

\begin{tabular}{|c|c|c|c|c|}
\hline \multirow{2}{*}{ Parameter } & \multicolumn{2}{|c|}{ Acidic soil } & \multicolumn{2}{|c|}{ Alkaline soil } \\
\hline & Control & Irrigation with the leachate & Control & Irrigation with the leachate \\
\hline Yield & $1.2975 \mathrm{a}^{*}$ & $2.415 b$ & $2.2375 b$ & $1.415 a$ \\
\hline \multicolumn{5}{|c|}{ Physiological parameters } \\
\hline$L$ & $47.73 b$ & $46.65 a b$ & $45.6 a$ & $47.28 \mathrm{~b}$ \\
\hline a & $-20.83 a$ & $-21.84 b$ & $-21.29 a$ & $-21.42 a b$ \\
\hline$b$ & $30.53 a$ & $31.65 b$ & $29.92 a$ & $30.28 a$ \\
\hline \multicolumn{5}{|c|}{ Chemical parameters } \\
\hline ash $\mathrm{g} / \mathrm{kg}$ & $187.3(5.3)^{\star *}$ & $177.6(6.9)$ & $136.8(4.2)$ & $163.5(7.8)$ \\
\hline $\mathrm{N} \mathrm{g} / \mathrm{kg}$ & $41.02(2.32)$ & $44.48(2.89)$ & $31.35(1.65)$ & $41.17(3.02)$ \\
\hline $\mathrm{S} \mathrm{g} / \mathrm{kg}$ & $1.837(0.08)$ & $1.505(0.12)$ & $1.582(0.10)$ & $1.242(0.09)$ \\
\hline $\mathrm{P} \mathrm{g} / \mathrm{kg}$ & $10.76(0.26)$ & $7.63(0.32)$ & $4.64(0.36)$ & $3.67(0.29)$ \\
\hline $\mathrm{Kg} / \mathrm{kg}$ & $53.76(1.75)$ & $47.44(1.80)$ & $23.33(0.97)$ & $24.77(2.09)$ \\
\hline $\mathrm{Na} \mathrm{g} / \mathrm{kg}$ & $0.11(0.02)$ & $2.40(0.07)$ & $0.09(0.01)$ & $7.47(0.72)$ \\
\hline $\mathrm{Ca} \mathrm{g} / \mathrm{kg}$ & $5.23(0.11)$ & $5.48(0.27)$ & $9.66(0.48)$ & $10.33(0.28)$ \\
\hline $\mathrm{Mg} \mathrm{g} / \mathrm{kg}$ & $1.96(0.01)$ & $2.76(0.06)$ & $4.46(0.21)$ & $4.11(0.11)$ \\
\hline Cu mg/kg & $9.45(0.19)$ & $8.53(0.28)$ & $6.40(0.29)$ & $10.60(0.14)$ \\
\hline Zn mg/kg & $129.93(9.00)$ & $126.69(10.86)$ & $28.98(2.18)$ & $80.9(74.60)$ \\
\hline $\mathrm{Mn} \mathrm{mg} / \mathrm{kg}$ & $111.89(1.59)$ & $93.75(5.48)$ & $43.07(2.57)$ & $44.38(1.76)$ \\
\hline $\mathrm{Fe} \mathrm{mg} / \mathrm{kg}$ & $77.57(12.76)$ & $50.40(3.13)$ & $72.46(2.86)$ & $86.42(4.55)$ \\
\hline $\mathrm{B} \mathrm{mg} / \mathrm{kg}$ & $4.24(0.10)$ & $2.03(0.25)$ & $7.19(0.27)$ & $10.78(1.73)$ \\
\hline
\end{tabular}

Note: * Homogeneous groups in the variance analysis; ** (SD) - standard deviation.

cultivation conditions on soil with high $\mathrm{pH}$, excess nutrients in leachates was unfavourable for maize development.

Physiological development of plants confirms the quantities of nitrogen taken up, calculated from Table 2. Analogously to the yield, in the case of acidic soil, the component amount taken up by plants was twice as high, and in the case of alkaline soil $-17 \%$ less.

When analysing total elements from Table 3 in the soil, it is worth noting that compared to the control, the leachate treatment had a higher sodium content by $81 \%$ for acid soil and $140 \%$ for alkaline soil, while calcium by $12 \%$ and $3 \%$, respectively. The change of soil saturation with alkaline cations was confirmed by the soil electrical conductivity. Especially for acidic soil, the increase in EC was significant: from 0.226 to $1.120 \mathrm{mS} / \mathrm{cm}$.

In treatments in which the leachate was applied, significant differences in the intensity of leaf colour indices were found (Table 2). Differences occurred especially for colour brightness (parameter L) in the treatment with alkaline soil. In the case of plants grown on acidic soil, after leaching, the plants were darker, more green and yellow rather than red or blue. These results confirm the amount of dry matter collected.
From the point of view of the retardation of unfavourable changes in the soil environment, coconut fibre substrate is becoming more important, as this is an organic matter that could be introduced into the environment in certain doses. This waste is not included in the list of wastes containing large quantities of organic material, excluding sewage sludge which may be introduced into the environment by the R10 method.

The Regulation authorises the use of waste assigned the code ex 020183 - Leachate media from hydroponics. In the case of leachate media, an acceptable dose of waste must be established, which takes into account the abundance of soil, the way it is used, the quality of the waste and the nutrient requirements of the plants, as well as the principles of good agricultural practice. The leachate medium should also be used outside the growing and development period of plants intended for direct human consumption (time from sowing or planting to harvest). To a certain extent, this eliminates the possibility of using leachate in horticultural farms, which are unlikely to have areas planted with cereals or industrial crops. The use of leachate must not cause any deterioration in the quality of soil, ground and surface water and groundwater, even if used for a long time. In particular, it must not cause damage to 
Table 3. Selected soil properties

\begin{tabular}{|c|c|c|c|c|}
\hline \multirow{2}{*}{ Parameter } & \multicolumn{2}{|c|}{ Acidic soil } & \multicolumn{2}{c|}{ Alkaline soil } \\
\cline { 2 - 5 } & Control & Irrigation with the leachate & Control & Irrigation with the leachate \\
\hline $\mathrm{pH}_{\mathrm{H} 2 \mathrm{O}}$ & 4.55 & 4.68 & 7.58 & 7.39 \\
\hline $\mathrm{pH}_{\mathrm{KCl}}$ & 4.13 & 4.29 & 7.69 & 7.50 \\
\hline $\mathrm{EC} \mathrm{mS} / \mathrm{cm}$ & $0.317(0.004)^{*}$ & $0.688(0.007)$ & $0.226(0.006)$ & $1.12(0.009)$ \\
\hline \multicolumn{5}{|c|}{ Total elements } \\
\hline $\mathrm{N} \mathrm{g} / \mathrm{kg}$ & $2.07(0.10)$ & $2.11(0.11)$ & $0.71(0.03)$ & $0.69(0.02)$ \\
\hline $\mathrm{S} \mathrm{g} / \mathrm{kg}$ & $0.21(0.01)$ & $0.23(0.01)$ & $0.20(0.01)$ & $0.23(0.01)$ \\
\hline $\mathrm{P} \mathrm{g} / \mathrm{kg}$ & $0.90(0.01)$ & $0.90(0.03)$ & $0.21(0.01)$ & $0.21(0.01)$ \\
\hline $\mathrm{K} \mathrm{g} / \mathrm{kg}$ & $2.03(0.17)$ & $2.08(0.02)$ & $0.55(0.01)$ & $0.62(0.06)$ \\
\hline $\mathrm{Na} \mathrm{g} / \mathrm{kg}$ & $0.21(0.00)$ & $0.38(0.01)$ & $0.15(0.00)$ & $0.36(0.03)$ \\
\hline $\mathrm{Ca} \mathrm{g} / \mathrm{kg}$ & $1.38(0.08)$ & $1.55(0.05)$ & $3.78(0.32)$ & $3.91(0.10)$ \\
\hline $\mathrm{Mg} \mathrm{g} / \mathrm{kg}$ & $2.62(0.05)$ & $2.67(0.11)$ & $0.77(0.01)$ & $0.82(0.01)$ \\
\hline
\end{tabular}

Note: * (SD) - standard deviation.

the environment. Leachates cannot be used on highly permeable soils, in particular loose and poorly clayey sands and light clay sands, if the groundwater level is not less than $1.5 \mathrm{~m}$ below the ground surface. The owner has study results confirming the quality of waste and the quality of soils on which the waste is to be used.

The concept of vertical farms is to close the circulation of matter and energy. Apart from problem solutions, e.g. by using leachate medium from hydroponics, there are no data in the literature about the ecological footprint of garden installations from cradle to grave. It seems that the environmental impact of production should be analysed in this area. It is possible to clean the leachate in membrane systems, but even here it leaves residue from equipment cleaning and its concentration in the retentate is increased. The practical implementation will have to take into account a number of environmental and technological aspects, some of which are not even known yet. Apart from solving infrastructure problems and reducing energy costs, the issues concerning all waste generated in hydroponics should also be regarded as very important (Bryszewski 2019). This is primarily due to concentration and the scale of production.

\section{CONCLUSION}

Due to the possibility of retarding the loss of nutrients for plants and water, recirculation or recovery of leachate is an important element of modern technology. The application of leachate, despite very low concentrations of these components, must be performed taking into account the properties of the substrate/soil, the requirements of the plant and the dose of leachate.

The introduction into the soil of leachate from hydroponics may lead to salinisation. From the point of view of the leachate fertiliser value, the source of water for fertigation and the component concentration in the media, which can cause ion imbalance, remain important.

\section{Acknowledgements}

1. Research funded under the project no. RPMP.01. 02.01-12-0430/16 entitled: Development of an optimal, innovative model for growing everbearing strawberry in modern gutter systems under covers on soilless substrate.

2. The Research was financed by the Ministry of Science and Higher Education of the Republic of Poland.

\section{REFERENCES}

1. Bryszewski, K.Ł. 2019. Szybkość usuwania azotu i fosforu z syntetycznych ścieków ogrodniczych. Nauka, Badania i Doniesienia Naukowe 2019, 16.

2. Dyśko, J. 2007. Problemy w bezglebowej uprawie pomidora $\mathrm{w}$ zamkniętym układzie nawożenia $\mathrm{z}$ recyrkulacją pożywki. Materiały Kongresu Agrotechniki Szklarniowej. Warszawa 2007, 52-57.

3. Dyśko, J., Kaniszewski, S., Kowalczyk, W. 2013. Wpływ bezglebowych upraw szklarniowych na zanieczyszczenie płytkich wód gruntowych odciekami nawozowymi. Infrastruktura i Ekologia Terenów Wiejskich, (2/I). s. 127-135

4. Górna, A., Górny, K. 2019. Perspektywy wykorzystania rolnictwa miejskiego jako nowej formy turystyki miejskiej-przykład Singapuru. 
Turystyka Kulturowa, 2, 69-83.

5. Kaniszewski, St. pod red. 2015. Rewitalizacja ekosystemu glebowego. Opracowano w ramach projektu „Nowe środki ulepszania gleby do redukcji zanieczyszczeń i rewitalizacji ekosystemu glebowego-BIOREWIT'LIFE+LIFE10ENV/PL/ Skierniewice 2015 ISBN 978-83-89800-72-5, ss.153

6. Kopeć, M., Mierzwa-Hersztek, M., Gondek, K., Zaleski, T., Bogdał, S., Bieniasz, M., Błaszczyk, J., Knaga, J., Nawrocki, J., Pniak, M. 2019. Variability of nutrients in the leachates from everbearing strawberry cultivated in soilless conditions on gutters. Acta Sci. Pol. Formatio Circumiectus, 18 (4), 13-23.

7. Kostecka J.2019. EcologicalEngineering-a View on Tasks and Challenges. J. Ecol. Eng. 20(10), 217-224. DOI: https://doi.org/10.12911/22998993/113538

8. Malorgio, F., Scacco, M., Tognoni, F., Paradossi, A. 2001. Effect of nutrient concentration and water regime on cut rose production grown in hydroponic system. Acta Hort. 559, 313-318.

9. Marosz, A. 2015. Retencja wody opadowej i jej wykorzystanie do nawadniania roślin na przykładzie modeli dwóch gospodarstw roślin ozdobnych w 2014 roku. Infrastruktura i Ekologia Terenów Wiejskich, (I/1).

10. Mojski, J., Kalaji, H., Swoczyna, T., Milecka, M., Widelska, E. 2018. Adaptacja hydroponicznego systemu ogrodów wertykalnych do warunków Polskich. Inżynieria Ekologiczna, 19(1)

11. Oleszczuk, N., Castro, J.T., da Silva, M.M., Korn, Md., Welz, B. \& Vale, M.G. 2007. Method development for the determination of manganese, cobalt and copper in green coffee comparing direct solid sampling electrothermal atomic absorption spectrometry and inductively coupled plasma optical emission spectrometry. Talanta 73(5), 862-869. doi:10.1016/j.talanta.2007.05.005

12. Sanjuan-Delmás, D., Josa, A., Muñoz, P., Gassó, S., Rieradevall, J., Gabarrell, X. 2020. Applying nutrient dynamics to adjust the nutrient-water balance in hydroponic crops. A case study with open hydroponic tomato crops from Barcelona. Scientia Horticulturae, 261, 108908.

13. Stankiewicz, B. 2017. Idea wertykalnych farm miejskich w obiektach poprzemysłowych w Aglomeracji Górnośląskiej na tle uwarunkowań upraw rolnych w województwie. Studia Ekonomiczne, 320, 87-106.

14. Syliwoniuk-Wapowska, A. 2017. Rolnictwo w arabskich monarchiach Zatoki Perskiej: główne problemy i tendencje. Wieś i Rolnictwo, 175(2), 93-118.

15. Żarnowiec, W., Bogdał, A., Rajda, W. 2014. Losses of water and nutrients in drip irrigation system of greenhouse cultivation. Acta Scientiarum Polonorum. Formatio Circumiectus, 13(4), 289-299. 